\title{
Electrochemical Analysis of AA6082 Aluminium Alloy in Chloride Media
}

\author{
Klodian Xhanari ${ }^{1,2}$, Matjaž Finšgar ${ }^{1, *}$ \\ ${ }^{1}$ University of Maribor, Faculty of Chemistry and Chemical Engineering, Smetanova ulica 17, 2000 \\ Maribor, Slovenia \\ ${ }^{2}$ University of Tirana, Faculty of Natural Sciences, Boulevard "Zogu I", 1001 Tirana, Albania \\ *E-mail: matjaz.finsgar@um.si
}

doi: $10.20964 / 2017.07 .71$

Received: 29 October 2016 / Accepted: 11 May 2017 / Published: 12 June 2017

\begin{abstract}
AA6082 aluminium alloy is widely used in the automotive industry. The aim of this study was to report on the corrosion behaviour of this alloy in 1 and $5 \mathrm{wt} . \% \mathrm{NaCl}$ solutions at $50{ }^{\circ} \mathrm{C}$ and to compare it to the results in the same solution at room temperature, using the weight loss and electrochemical techniques. The chosen concentration and temperature range are the most severe conditions in automotive corrosion tests. The localised and general corrosion rates are higher for the highest of the two temperatures tested. At both temperatures, corrosion occurs according to a kinetic-controlled process.
\end{abstract}

Keywords: corrosion; interfaces; aluminium alloy; weight loss; electrochemical impedance spectroscopy; cyclic polarisation;

\section{$\underline{\text { FULL TEXT }}$}

(C) 2017 The Authors. Published by ESG (www.electrochemsci.org). This article is an open access article distributed under the terms and conditions of the Creative Commons Attribution license (http://creativecommons.org/licenses/by/4.0/). 